\title{
The managerial turn and municipal land-use planning in Switzerland - Evidence from practice
}

New Public Management (NPM) reforms are intended to increase efficiency and support a more managerial approach to public problems. This paper examines how NPM-type reforms have led to the growing influence of finance and realestate departments in local level planning in Switzerland. Drawing on over 50 interviews, the paper maps the growing influence of flexible private-law or incentive-based instruments as complements to more binding instruments (typically zoning) in land-use planning practices. NPM reforms have prompted a renewed interest in public property, forcing municipalities to position themselves in relation to the necessity to sell or retain public land. The results show that NPM has affected practices of landuse planning in Switzerland, but the outcomes are more complex than a one-to-one takeover and there is variation across the country. The Swiss case study helps extend the wider international debate about NPM and planning. This paper highlights the complex impacts of managerialism on planning reform as well as ongoing tensions between increased efficiency in plan implementation and public scrutiny.

Keywords: managerial turn, property rights, land policy, policy instruments, New Public

Management, Switzerland

Source: Gerber J.-D. (2016). The managerial turn of municipal spatial planning in Switzerland. Toward land policy? Planning Theory \& Practice 17(2). 


\section{Introduction}

A growing literature of planning calls for a shift from passive planning procedures toward more active alternatives (Hartmann \& Spit, 2015; Healey \& Barrett, 1985; Knoepfel et al., 2012; Krabben \& Jacobs, 2013; Needham \& Verhage, 1998; Weber et al. 2011). This shift to more "active land policy" implies for planners a need to better support the implementation of land-use plans (a method of intervention typical of Weberian bureaucracies) with other policy instruments, in particular incentives or public intervention in property rights. It is argued that the shift toward more active strategies is necessary because the context of planning has changed; less greenfield development and more redevelopment are needed (VLP-ASPAN, 2013; Tillemans et al., 2012). Interestingly, this call for a more active approach to land-use planning parallels the "managerial turn" that has occurred in public administrations since the mid-1990s; the rationale of New Public Management (NPM) also leads to increased (cost)efficiency and to a more managerial approach to public problems (Mäntysalo et al., 2011; Sager \& Sørensen, 2011).

This article shows that in Switzerland proactive thinking in planning is not new; such approaches have been encouraged by the introduction of NPM in public administrations. This article analyzes the effect of NPM on the strategy of planners and explores connections between administrative reforms consistent with NPM and the active strategies used by municipalities to shape their spatial development. To what extent do the managerial practices promoted by NPM principles affect land-use planning practices? Did planners mobilize the readily available conceptual framework provided by NPM reforms to become more proactive?

This explorative (semi-quantitative) survey investigates the strategies followed by Swiss municipalities to implement their development strategies. It leads to a reflective inquiry on the meaning of the adaptations that occurred in Swiss planning administrations following NPM reforms. We show that NPM has affected the practices of land-use planning in Switzerland, but that the outcomes are more complex than a one-to-one takeover. The conceptual framework of NPM is omnipresent, but local municipalities are not passive in the face of the managerial doxa and reinterpret it according to their needs. In the concluding part of this article, we build on these findings to draw conclusions concerning the present move toward active land policy that is occurring with the 2003 major revision of the Swiss Federal Land-use Planning Law (Hengstermann \& Gerber, 2015). To that end, we build a typology of possible responses to NPM that shed light on the potentials and pitfalls of active land policy in Switzerland. 


\section{New public management}

\subsection{NPM paradigm}

Several studies on large-scale urban development projects show how the administrations of large cities have been influenced by neoliberal arguments concerning, in particular, public private partnerships (PPP) (Fainstein, 2008; Swyngedouw et al., 2002), which are also often advanced by the proponents of NPM. The NPM paradigm shares with neoliberal ideology a common faith in market-oriented management; for example, public administrations should model themselves on private firms (Dibben \& Higgins, 2004; Osborne \& Gaebler, 1992). As the expression of an ideology, NPM imposes a particular approach to understanding public problems, to framing the mental interpretation of these problems and to imposing specific values. NPM also leads to the use of a specific set of practical tools, instruments, and methods that are supposed to provide an answer to the problems it has prompted actors to identify. Consequently, NPM has a dual nature; it is both a framework to interpret the world - which is referred to in this article as the NPM paradigm - and a set of tools and practices, which are the concrete manifestation of the NPM paradigm.

Since the 1980s, the NPM paradigm has resulted in a shift from administration to management (Hughes, 2003). In connection with land-use planning, we appraise NPM as a comprehensive managerial approach ("managerial turn") that aims to replace performanceinhibiting control elements of the political-administrative system through management systems, structures and instruments inspired by the private sector. The main characteristic of administrations run according to NPM principles is that they advance the intended and measurable effects expected through public service provision rather than through available financial, personal and material resources (inputs). Public authorities all implement NPM principles differently, prioritizing one aspect or another depending on the problems to be solved, political majorities, or available experience.

\subsection{New public management in Swiss municipal administration}

The organization of the State in Switzerland is characterized by three executive levels: the more than 2300 political municipalities (local authorities), the 26 cantons and the Confederation. They work together in a form of "cooperative federalism", i.e., "the completion of federal legislation by the cantons, the implementation of federal programs by cantonal and municipalities, and extensive finance - and revenue - sharing" (Linder, 1994, p. 55).

A survey performed in the mid-2000s revealed that fewer than 5\% of Swiss municipalities have officially introduced NPM in their administration (Steiner \& Ladner, 2006). There is no boom of NPM in Switzerland at the local level. However, the percentage of municipalities using NPM methods increases proportionately with their size. The main reasons 
are that they are facing much more complex problems and that they have larger administrations and corresponding know-how (Steiner \& Ladner, 2006). The authors of this study note that it would be wrong to underestimate the role of NPM. Many municipalities have achieved a series of reforms while moving toward NPM, e.g., definition of mission statements, separation of strategic and operative tasks, outsourcing of specific tasks, incentive wages, and abolishment of civil servant status. Although not all municipalities refer to NPM, many of them have achieved reform of their public management. Very often, NPM reforms are introduced only in selected departments of the administration. One can speak of a consolidation of public management practices involving elements of NPM rather than a booming expansion (Ritz, 2005; Steiner \& Ladner, 2006). This mix of new types of management with Weberian bureaucracy result in what Pollitt and Bouckaert call "neo-Weberian public administration" (2011). The NPM paradigm always interferes with other variables such as the political culture or the political system.

Although debates about NPM were virulent in the 1990s (Knoepfel et al., 1995), today, with the benefit of hindsight, the approach to NPM appears more pragmatic. It appears that Swiss municipalities have appropriated, reinterpreted, and made these ways of thinking theirs (Schedler, 2003). The challenge for the present study of cryptic but pervasive NPM-induced representations is to grasp new practices performed in the spirit of NPM but not necessarily labeled as such.

\subsection{NPM and Swiss land-use planning}

Different authors have analyzed and described the long-term transformations of land-use planning practices in Switzerland in connection with new forms of urban governance, such as the role of public-private partnerships and the urban economics of large urban developments (Theurillat \& Crevoisier, 2013; 2014), contemporary changes in specific urban planning instruments (Matthey, 2014; Schuler \& Ruzicka-Rossier, 2011; Süess \& Gmünder, 2005), contemporary socio-spatial reconfigurations linked with mobility (Söderström et al., 2012; Kaufmann \& Faith Strelec, 2011), or challenges linked with densification (Scholl \& Elgendy, 2011). However, few analyses have focused on the changing use of policy instruments in planning (but see Ruegg, 2008; Weber et al., 2011).

The present article builds on the last research strand and focuses on the reasons explaining these changes. An emerging trend in land-use planning research (e.g., in the context of the International Academic Association on Planning, Law, and Property Rights) claims that privatelaw instruments (including property) such as those used by public actors must also be assessed to understand the full effect of planning practices (Knoepfel et al., 2012). Correspondingly, the influence of the NPM paradigm on spatial development will be addressed at the meeting point of the activities of planners, public real-estate managers and finance units who all address 
different policy instruments.

\section{Research question 1}

Municipalities are conceptualized as heterogeneous entities whose members (legislative, executive, city planners, public funds managers, and building managers) defend partially different interests but share the need to assert themselves in a competitive context in which their competences are challenged by private or public actors defending competing agendas (Hersperger et al., 2014). Often, the capacity of the political authority to govern depends less on electoral success and political majorities than on its capacity to cooperate with private/corporate actors, including landowners and developers, endowed with resources appropriate for undertaking urban development programs (Pierre, 1999; Stoker, 1995). To frame our exploration of the influence of the NPM paradigm on the spatial development strategies of municipalities, the first research question addressed in this article is, how do the NPM reforms modify the configuration of actors in charge of land-use planning at the local level? How are these actors - including finance units who are often simultaneously in charge of public real estate and budgetary efficiency - involved in decision-making about spatial development?

Hypothesis 1: Effect of NPM reforms on the configuration of actors. The effect of reforms is characterized by a shift in the balance of power among actors, resulting in a greater importance given to the finance department, which is often in charge of public real estate, at the expense of planners. We expect NPM reforms to have a threefold consequence on the configuration of actors: (1) increased competition within and among municipalities for scarce resources, (2) increased importance of monetary considerations in land-use planning and strategic real-estate management, and (3) increased involvement of private actors (e.g., through public-private partnerships).

\section{Research question 2}

Public actors can rely on different policy instruments to implement their strategies. Policy instruments refer to, for example, regulation, education, information, market mechanisms, incentives, taxes, and public ownership. The selection of policy instruments is often presented functionally, as though the choice only depends on mere technical choices (Lascoumes \& Le Galès, 2005, p. 11). However, instruments are not axiologically neutral; they are value loaded, correspond to a specific interpretation of the role of the state and/or its private partners, and denote a precise conception of intervention mechanisms (Salamon, 2002). Public policy instruments structure the social relationship between a public authority and the target groups according to the representations and meanings that they are carrying (Lascoumes \& Le Galès, 2005 , p. 13). As such, the selection of policy instruments generates political activity. This 
allows us to formulate the second research question addressed in this article: - Considering that the NPM paradigm is expected to go together with a change in the range of mobilized policy instruments, will flexible private-law or incentive-based instruments be privileged at the expense of more binding instruments (typically zoning) in daily land-use planning practices? Which instruments stemming either from public or private law do municipalities use within the spatial development process?

Hypothesis 2: Effect of NPM reforms on the range of mobilized policy instruments. We expect to observe a shift toward flexible instruments such as private-law and incentive-based instruments because they provide more freedom to the local administration and to private/corporate partners than does strict regulation. Conversely, the importance of binding plans and full public property will decrease.

At this point, a word of caution is needed. It is important to acknowledge that NPM reforms are of course not the only parameter influencing strategies. The planning context is always changing, particularly because greenfield development is diminishing, and the pressure to redevelop existing neighborhoods or industrial brownfields is increasing. This article does not minimize the changes that occur independently of NPM reforms but argues that the NPM paradigm provides specific answers to the questions arising from the changing context.

\section{Policy instruments of land-use planning}

Governments, in general, and municipalities, in particular, use different tools or instruments to perform social control. "What government does to us - its subjects or citizens - is to try to shape our lives by applying a set of administrative tools, in many different combinations and contexts, to suit a variety of purposes" (Hood, 1983, p. 2).

Following the classic, hierarchical Weberian model of administration that implies impersonality, concentration of administrative power and a leveling effect on social and economic differences (Weber, 1968), a hierarchical structure of plans regulating land use has evolved in Switzerland, a process orchestrated by the Federal Land-use Planning Law of 1979. Consequently, the supply of land is not simply a matter for the landowner; it is greatly influenced by municipalities that are in charge of delimiting building land from agricultural land through zoning and enacting building regulations.

As in many other countries, municipalities grant development permits to landowners provided that their permit application conforms to zoning designations. Although plan making is proactive, providing a vision of local development for the next decades, plan implementation is reactive, as regulators await private development proposals and respond to them (Fulton, 
1999). Therefore, there is always a gap between the real supply of developable 'parcels' (depending on the willingness of landowners to sell or to develop) and the potential supply (depending on land-use plans) (Davy, 2000). Once they have defined the potential supply of developable parcels, municipalities might develop strategies to address this gap. To be more proactive, a municipality can rely on several instruments to bring the practical supply of developable land to equal the potential supply such as that planned by land-use plans. We refer to all the means implemented by a municipality to match the real supply with the potential supply of parcels as an active land policy (Hartmann \& Spit, 2015; Hengstermann \& Gerber, 2015). An active land policy refers to all public decisions and actions aiming to implement politically defined spatial development goals through changes in the use, distribution and value of land (Healey \& Barrett, 1985; Krabben \& Jacobs, 2013; Needham \& Verhage, 1998).

We examine three "families" of tools: (1) the different types of plans, (2) the framework affecting spatial development decisions (i.e., information and incentives), and (3) private law instruments. Public law involves the state using its authoritative power, including regulatory statutes, penal law and other laws of public order. It is distinguished from private law, which addresses relationships between individual or corporate actors (i.e., property law, the law of contracts, torts and obligations). In general terms, public law involves interactions between the state and the general population, whereas private law involves interactions between private actors. Governments can also establish a private relationship with private or corporate actors, which also falls within the definition of private law in this particular case.

\subsection{Types of plans}

Plans are the classical instruments of land-use planning (Bühlmann et al., 2011; Muggli, n.d.). Plans are the responses by public authorities to the problem of uncoordinated territorial development that might result from unrestrained property-title holders (Adams et al., 2002; Jacobs \& Paulsen, 2009; Zimmerli, 1990). Fighting against uncoordinated spatial development leading to the loss of agricultural land, sprawl, and so forth, is the main goal of the Swiss national land-use planning policy and has not changed since the introduction of the Land-use Planning Law in 1979. We focus on two main dimensions of spatial plans in connection with NPM principles: their flexibility (i.e., their non-binding character to public actors) and the degree of involvement of private actors.

In Switzerland, local zoning plans, which must comply with cantonal structure plans, are binding on land owners. The complete revision of local zoning plans is a lengthy process that occurs every fifteen years. To allow for more flexibility, some municipalities develop their own strategic plans, such as master plans. These plans can be a preliminary step toward a legally recognized plan (such as a municipal structure plan), they can become contractually 
binding as such if the different partners who took part in the elaboration of the plan sign it, or they can be used as guidelines in issues that are not covered by other plans.

Comprehensive and local zoning plans are prepared by public authorities. However, private developers might be asked to prepare and fund design plans (district plans), particularly if public space is not the primary concern of the new development; in any case, the final validation of the plan is always done by a public authority.

\subsection{Framework conditions affecting decisions}

Municipalities can use different instruments to influence the actions of landowners and developers without formally constraining them; i.e., municipalities can provide incentives and information. This type of instrument is very much in line with NPM principles because it leaves private actors free to choose whether they want to behave according to the incentive.

There are many types of incentives; however, not all of them are available to municipalities. For instance, municipalities have no room for maneuver to tax the activities that they do not want to happen; the cantonal authority is in charge of taxation. However, municipalities can financially encourage specific activities (e.g., renovation of representative buildings) if they develop a dedicated fund.

Land deals are particularly opaque in Switzerland because there is no public statistical information about the price of transactions. Moreover, it is often difficult for a firm that is seeking to purchase land to know which landowners might be willing to sell. Consequently, to increase their attractiveness, some municipalities have developed a specialized service dedicated to providing this information and facilitating the installation of firms or private individuals. The facilitator helps to link potential new settlers, landowners seeking potential buyers and planning authorities in charge of permit deliverance.

\subsection{Private law instruments}

Land-use plans appear to be ever more challenged by instruments of private law, whose implementation is considered more flexible and efficient because it can be done partly outside of the political arena. Contractual agreements, public-private partnerships, and collaborations with other public actors result in a shift of responsibilities from the legislative to the executive. These transactions might be primarily treated as private and become partially opaque to public scrutiny (Morris, 2008). A re-scaling of the governance of land-use planning occurs (Cheever, 1996; Wright \& Czerniak, 2000).

Property titles in general play an important role in shaping land use (Jacobs \& Paulsen, 2009). Land titles can be either used by public authorities to complement land-use planning or used by private/corporate actors to defend their own development agenda (Knoepfel et al., 2012; Nahrath, 2005). 
Many public actors were already using private law instruments before NPM reforms (Sieber, 1970; Zimmerli, 1990). Indeed, direct provision of services (e.g., through public real estate and corresponding servicing) fits well with pre-NPM practices (Leman, 2002). No one-toone relationship between NPM principles and the use of private law instruments can be established. However, we claim that although the instrument is the same, the reason for its use is different. Schematically, although the legitimation of public ownership was in essence seen in its ability to improve the provision of services to the public, under the NPM paradigm, public ownership is considered a means to circumvent direct public scrutiny to accelerate procedures.

\section{Methods}

\section{1. $\quad$ Procedure followed in the analysis}

To highlight the effect of NPM reforms on the configuration of actors and to evaluate their choice of policy instruments to steer spatial development, a broad survey of nineteen Swiss municipalities was performed.

To ensure comparability, the goal was to select municipalities sharing similar constraints. The typology of Swiss municipalities developed by the Swiss Federal Office of Statistics was used to produce a list gathering all of the municipalities belonging to the statistical types "center" or "suburban municipality" (Schuler et al., 2005). Suburban municipalities are located at the periurban fringes of a larger city. To narrow down the choice, municipalities described as "large centers" were removed from the sample (because their territory is totally urbanized). Smaller municipalities with a total population of less than 15,000 inhabitants were also omitted (population size was used as a rough proxy for the size of the administration). Among the fifty-eight municipalities that fulfilled these criteria, nineteen were selected in the cantons to the north of the Alps (Table 1).

In each municipality, city planners, public managers in charge of real-estate assets (including buildings), and political members of the executive were interviewed using a standardized question set and semi-directive face-to-face interviews ( $\sim 60 \mathrm{~min})$ to obtain a general picture of spatial development strategies. A total of 53 interviews (in four of them, one interviewee answered in the name of two administrative services) were conducted. After a preliminary phase addressing general organizational characteristics of the municipality (including the administration's organization, the tasks of the different organs, and internal decision-making procedures), the interviews focused on two main issues:

- Local effects of NPM reforms in the context of municipal spatial development (from $t_{-}$ ${ }_{1} \cong 1990$ to $=2010$ ). The effects of NPM reforms were evaluated according to three 
general trends that are at the core of the NPM paradigm: (1) increased competition for scarce resources, (2) increased pressure for financial efficiency, and (3) increased involvement of the private sector.

- Changing use of policy instruments (between $t_{-1}$ and $t_{0}$ ). Three broad categories of instruments were discussed: (1) land-use planning instruments (plans), (2) framework conditions affecting spatial development (e.g., taxes and incentives) and (3) private-law instruments (e.g. property and contracts).

The objective was to assess the role played by NPM reforms by understanding the reasons for the implementation of new strategies. For each question, interviewees were asked to decide on a scale of 1 to 5 whether the situation changed in comparison with the 1990s. Differences among the three categories of actors were analyzed using chi-square tests (Table 2).

Because the questions raised in the questionnaire are often complex, the semiquantitative data produced in the questionnaire were always analyzed in connection with the reasons provided by the interviewees to explain their choices on the scale. These qualitative data provide explanations for and contexts in which given instruments are used. After discussing the hypotheses, we used these data to make an additional step in the analysis and build inductively a typology of the municipal responses to NPM reforms (Table 3). Ideal types are mental constructs resulting from a deliberate simplification and exaggeration of crucial aspects of the empirical reality (Weber, 1968). By stressing certain dimensions of the given phenomena common to several cases, ideal types provide standards to compare and interpret empirical data. The different ideal types are not mutually exclusive in the sense that a given municipality can present characteristics of different types.

The selected cases provide a broad picture of suburban municipalities' strategies. These municipalities are on the front line to manage growing urbanized areas. Their strategies are not representative of all Swiss municipalities but provide a good overview of the possible responses that a public actor can formulate when pressed to address spatial development issues.

\section{[Table 1]}

\section{Results}

\section{[Table 2]}

\subsection{Effects of NPM reforms on the spatial development practices of municipalities}

Competition. Although financial resources have become scarcer, most interviewees agreed that competition for resources within municipalities has decreased. The fact that no significant differences of opinions were observed among the three categories of actors interviewed 
(politicians, planners and public real-estate managers) is a clear indicator that their shared perception of the problems results from a close coordination of their activities (Table 2). Two main factors explain this trend: administrative reforms tend to call for more output-oriented procedures, which often require different administrative units to collaborate (in our case, planning with finance departments). Simultaneously, increased competition among municipalities requires municipalities to muster their strength more efficiently. Large development initiatives are often triggered by external funding stemming from higher levels of government, in particular the Federal administration. Municipalities enter into new alliances with neighboring municipalities to meet the requirements of the financial backer (e.g., in the context of the "agglomeration policy" of the Swiss Confederation). Consequently, although overall competition among municipalities has increased because of scarcer financial resources, municipalities collaborate more closely with their direct neighbors because of the strong incentives provided by the Federal level. In line with the principles of NPM, these incentives are the result of a shift from a rather undifferentiated spreading of funds in regional development toward a more targeted form of project-oriented support.

Financial efficiency and the management of real public assets. New standards for the presentation of financial statements (e.g., the IPSAS ${ }^{1}$-model) have been (or are in the process of being) introduced in most municipalities. These new rules, inspired by the private sector, press municipalities to evaluate their real assets at their market value, whereas, in the past, these assets used to disappear from the books after they had been amortized. In accordance with NPM precepts, these new accounting standards increase transparency (true cost, disappearance of hidden assets, cancellation of cross-financing), cost consciousness, and comparability (benchmarking). However, they also have "side effects" on public real estate; the main focus becomes the financial value of real estate instead of, for example, its "strategic" value (i.e., capacity to influence spatial development through property titles), option value, historical value, or amenity value. These accounting reforms lead to the monetization and commoditization of public real estate. Several interviewees signal an increased short-term interest in municipal real estate from politicians who think that its sale is the solution to pay off municipalities' debts (e.g., municipality of Aarau in the 1980s and 1990s). The relationship between municipalities and their real assets reflect a complex reality with opposing trends. Some municipalities have only a minimal amount of real assets or have sold them all. Realizing that real assets are an important resource, these public actors are often willing to acquire strategic parcels for new development projects (e.g., municipality of Aarau in the 2000s or municipality of Carouge). In

\footnotetext{
${ }^{1}$ IPSAS stands for International Public Sector Accounting Standards
} 
contrast, some municipalities own considerable amounts of real assets (e.g., municipalities of Biel/Bienne or Illnau-Effretikon). Facing important maintenance costs, these public actors are ready to sell the parcels which appear to be less important for their future development. Despite different specific situations, two trends emerge from the interviews: a renewed interest in public land acquisition as a means to influence development and an increasing pressure to optimize real asset portfolios (leading to sales and acquisitions).

Public-private partnerships. Interviews reveal an ambiguous attitude toward PPP. Many municipalities have entered partnerships with private service providers, but few have done so in connection with spatial development issues. Although almost all authorities pretend to be open to PPP, which is in line with NPM precepts, there is a clear skepticism about the long-term effects of such partnerships (particularly concerning responsibilities if the private partner defaults or goes bankrupt). Ultimately, it appears that municipalities only enter PPP if they have no other choice, i.e., no possibilities to finance targeted development on their own.

\subsection{Evolution of practices in the selection of policy instruments in land-use planning}

'Standard' land-use planning instruments (public law). It appears that local land-use plans (zoning) and corresponding zoning ordinances remain fundamental tools of land-use planning; they are binding on landowners and exercise, as such, a major influence. In parallel to their need to establish a predictable framework through zoning, municipalities are confronted with planning tasks that are increasingly demanding and complex. In this context, the strategic dimension of structure plans is sought by many municipalities; they provide general guidelines to approach the complexity of today's planning tasks. Flexible plans, such as masterplans, guidelines and other non-binding plans, also play an increasingly important role, either as internal guidelines for public authorities or as preliminary documents in the negotiations of more binding types of plans. Another trend revealed by the interviews is the rising importance of district plans, which is due to an increasing concern of municipalities for building quality; compulsory district plans allow for better control of development (for instance, when architectural contests are mandated). Overall, it appears that, since the 1990s, local zoning plans have been complemented by many other plans, each of which responds to specific needs. However, this increasing complexity in the use of planning instruments did not occur at the expense of land-use plans. Flexible instruments complement land-use plans but do not replace them.

Interventions through the redefinition of framework conditions affecting decisions. Incentives, which make it possible for public authorities to avoid resorting to constraining measures such as 
bans or obligations, are gaining momentum, although they have not yet been widely introduced at the local level. Indeed, municipalities do not have the power to introduce new taxes. However, most of them have developed new funds to subsidize energy-saving measures or historic building preservation. A special type of incentives is the opportunity provided to newcomers to rely on the facilitating role played by dedicated public actors. The mayor coordinates the different services of the local administration to facilitate the settling down of companies or (mostly wealthy) inhabitants. Additionally, many municipalities have a dedicated person or service in charge of this task. However, the responsibilities, scope of intervention and mission of these services vary greatly. They are more developed in peripheral regions because of the special effort that is needed to attract companies or inhabitants (e.g., municipality of La Chaux-de-Fonds). In regions with rapid economic growth (e.g., municipality of Bulle), the challenge is to channel development rather than to attract potential newcomers.

Intervention through private-law instruments. Although PPP remain uncommon, solutions tailored to the requirements of individual landowners or developers have become more widespread because target groups of land-use planning policies have become more demanding in discussing public decisions that might jeopardize their interests. In the same vein, publicprivate arrangements concerning non-monetary compensation have increased. In negotiations concerning private district plans, private developers can ask for derogatory clauses to the zoning regulation in force (in particular concerning building density) if they comply with quality/technical standards or if they commit themselves to new developments that meet the public interest. Through this mechanism, municipalities can obtain specific improvements to the project (such as additional classrooms, social housing, energy-efficient buildings, or rooms for assistance to drug addicts) on private parcels. The main challenge of this type of instrument is for partners to author an agreement that satisfies both parties. The use of non-monetary compensation is by no means new; however, some municipalities have recently started to have higher expectations before granting derogatory measures. Municipalities who follow this strategy have found an economical means of gaining private participation in the execution of public infrastructure. However, plans specifically tailored to the requests of individual developers, including negotiated derogatory measures, raise the sensitive question of legal certainty and legal equality among citizens.

Other important private-law instruments are long-term building leases. Building leases continue to be used extensively by those municipalities that have a long-term land policy (e.g., municipality of Biel/Bienne). Municipalities lacking this long tradition and experience tend to avoid building leases and prefer to sell their real assets. This trend is reinforced by the fact that the public real-asset management literature, which largely relies on standards borrowed from the private sector, does not expand on building leases, which require much fine-tuning to avoid bad 
surprises at their expiration. Consequently, despite their many advantages for public authorities (e.g., public control of property titles, fight against speculation, and regular income), the use of building leases is not increasing.

For many public actors, public ownership appears to be the only solution to affect specific developments. Public actors are aware that land-use planning goals have no chance of being fulfilled in the face of well-protected private interests. To implement a more active land policy, public authorities might try to become landowners themselves. This strategy has a high financial cost. Some municipalities have created real asset acquisition funds, whereas others have special budget provisions for that purpose (e.g., municipality of Köniz). However, acquisitions are usually performed on a case by case basis. The performance of a municipality in the land market depends very much upon personal connections with landowners; because Swiss law does not provide public bodies a pre-emptive acquisition right in land deals and because financial details of land transactions are not public, the land market remains very opaque. Interviews reveal that giving oneself the means to enter this market (i.e., setting up a specialized administrative unit) is often the price to pay for a more active land policy.

\section{Discussion}

\subsection{Discussion of the hypotheses}

Hypothesis 1 is only partially confirmed. Overall, we observe more competition and benchmarking initiatives, increased concern for optimization and cost efficiency and intensified collaboration with the private sector. These changes are distinguishing features of NPM reforms. However, the effects of these reforms on actors are slightly different from our predictions. First, increased competition among municipalities appears to have encouraged cooperation within municipalities to promote competitiveness. Second, the increased importance of monetary considerations clearly gives a new role to finance and accounting specialists. However, this new role does not mean that finance departments take over real asset management. The effect of monetary considerations, and particularly of new accounting rules, is more subtle; public real estate tends to be evaluated according to its potential cash value rather than according to the strategic power and flexibility it might provide for the implementation of present and future spatial development decisions. Consequently, in many municipalities, landuse planning services are required to overcome a stronger resistance when they defend the formulation of land policies based on the acquisition of real estate. This "mixed feeling" toward public intervention through property titles has also been described in other countries (the case of the Netherlands is typical; Krabben \& Jacobs, 2013). Third, although most municipalities claim to be open to PPP, in reality, few of them risk entering such contractual relationships with the private sector. PPP are also clearly perceived as a potential risk, which might weaken their 
position. Financial issues raised by PPP have also been described elsewhere in scientific discussions (e.g., Theurillat \& Crevoisier, 2013, for the Swiss context).

Hypothesis 2 is only partially confirmed. Overall, the importance of flexible instruments (non-binding plans, private plans, incentives, facilitation, PPP, and non-monetary compensation) clearly increases. Conversely, the importance of stricter instruments does not tend to decrease; local plans are as important as ever, binding structure plans become more relevant, and even the importance of public real assets increases. At first, these results might seem surprising. They can be explained by parallel trends that interviews clearly reveal:

- A general need for more and better planning that considers the increasing complexity of spatial development calls for the use of a broader range of instruments, which is consistent with the international literature on active land policy.

- Flexible plans, which tend to complement standard binding plans rather than replace them, are particularly needed to open the door to direct negotiation with target groups, leading the way to more binding plans in a second step. The complementary nature of binding plans and flexible (negotiated) plans is evident in connection with legitimacy; whereas the former are legitimized through compliance with democratic rules (primary legitimacy), the latter are legitimized through the outputs generated due to closer cooperation with target groups (secondary legitimacy such as promoted by NPM) (Mäntysalo et al., 2011).

- The parallel development of private law instruments, which offers more room for maneuver to the executive and to the administration (at the expense of the legislative side), is actually a feature praised by the apologists for NPM. The greater importance given to public real estate must be understood in the light of the latter assertion; despite initial high acquisition cost and correspondingly heavy procedures, both of which contradict the slim state paradigm, public real estate is actually a tool that makes decision making concerning spatial development more flexible and more entrepreneurial (see typology below).

\subsection{New role for municipalities in spatial development}

By analyzing concrete policy instruments used by actors in charge of spatial development, this article reveals that public actors do not remain entirely without power or resource in the face of NPM reforms. Although under pressure to implement NPM, because its solutions impose themselves as self-evident in the context of the actual management and optimization-oriented doxa, municipalities are also under the influence of counter-movements and resistance strategies, a point that is particularly true in more urban settings in which these citizen initiatives are better established (Brenner, 2009; Eberlein, 1999; Harvey, 2008; Jessop, 2002; 
Larner, 2003; Whitehead, 2003). Consequently, it is not a surprise that interviews also reveal that municipalities do not implement NPM reforms passively but reinterpret its principles, adapt them to local specificities, or even distort them. As strategic actors, municipalities also use the new instruments promoted by NPM to defend their specific interests. Interviews reveal, in particular, that the spatial strategies of municipalities are influenced by development priorities resulting, for example, from the local socio-economic context, by how public actors legitimize their actions or by local traditions in connection with public intervention in the land market. These variables all influence how NPM reforms are implemented concretely.

The above explains why the studied municipalities do not all follow the same strategies, set the same priorities or pursue the same goals. Relying on a qualitative analysis of the interviews, we constructed a typology of responses to NPM reforms in connection with land-use planning strategies (Table 3):

- Laissez-faire strategy: This type of response to NPM is a one-to-one implementation of its principles. Because the NPM paradigm calls for a slimmer state through the redefinition of state action, a focus on operational missions, and the transfer of tasks to the private sector, those municipalities who maintain a low profile in land-use planning issues find a legitimation of their position in the principles of NPM.

- Reinforcement strategy: This type of response to NPM results from the selection of NPM principles that can help municipalities to be more proactive in land-use planning. In particular, the efficiency of procedures is advanced. Private law instruments are promoted whenever they might be useful to reinforce state control over spatial development. NPM is considered an opportunity to question present practices and to develop new strategies of state intervention.

- End-justifies-the-means strategy: The use of private law instruments, in particular public property or long-term leases, has a long history in some municipalities. The temptation is great among those public actors who own a great deal of land, including agricultural land, to play simultaneously on the zoning and property-title levels to maximize effects both on spatial development and profit. These municipalities tend to interpret NPM as a call to reinforce the executive at the expense of the local parliament. Municipalities that follow this strategy tend to behave as would any other private company in the land market and use public privileges as an asset they can take advantage of (Knoepfel et al., 2012).

\section{[Table 3]}




\subsection{Outlook: The new Swiss land-use planning legislation}

Drawing conclusions concerning the changing context of land-use planning - implying less greenfield development and more redevelopment - a major revision of the Swiss Federal Landuse Planning Law was passed in 2013 (in force since May 2014). In the first article of the law, the revision sets the tone; densification becomes a central goal of land-use planning. A new paragraph (in Art. 3) highlights the need to adopt measures guaranteeing better use of brown fields and unused areas located within building zones and to take advantage of densification opportunities. Through active land policy, local municipalities should become more proactive in the management of their spatial development. It is obviously too early to measure the effect of the new Land-use Planning Law on the strategies of planning authorities (local land-use plans are revised every fifteen years). However, the call for more active and managerial planning compels planners to question their role (Matthey 2015).

What do the results of the present study mean in the light of the 2013 partial revision of the Federal Land-use Planning Law? The present study shows that NPM reforms do not undermine the devising of active land policies. Quite the opposite is true: local authorities are able to reinforce their position through a more managerial approach ("Reinforcement strategy"). However, the increased use of private-law instruments can also lead to more secrecy within local administrations because comparative advantages are lost when land-deal negotiations become public ("End-justifies-the-means strategy"). More active strategies linked with NPM reforms also tend to lead to day-to-day forms of management that might foster innovative solutions but privilege short-term benefits over long-term ones. The lessons to be drawn in connection with the 2013 legal revision and the expected shift toward more active land policy is that increased use of private-law instruments can indeed lead to greater involvement of public actors in spatial development, increased efficiency and more complex intervention strategies; however this needs to be done without the pitfall of a focus on short-term solutions, reduced democratic participation and narrowly-defined finance-centered objectives. Thus, the challenge for local administrations will be to become more active but without falling into the trap of shortsighted managerialism.

\section{Conclusion}

Our study reveals that, despite the laissez-faire strategy followed by some municipalities, NPM reforms have not led to a rollback of the local state (Brenner, 1998) in planning matters. This perpetuation or even reinforcement of the public sector is counterintuitive because NPM is supposed to call for a lean state but has been observed elsewhere (Guillén, 2001; Swank \& Steinmo, 2002; Weiss, 1998). 
This study shows that many managerial practices promoted by NPM reforms have found an echo in planning practices. Direct causalities are difficult to demonstrate because no one-to-one takeover of NPM precepts can be identified. Some reforms are directly prompted by NPM principles, whereas some municipalities have used NPM as a source of inspiration in the quest for solutions to new challenges (such as densification, redevelopment of already built areas or the fight against land hoarding). Ultimately, the interactions between NPM reforms and land-use planning have had three main effects on daily planning practices. (1) They prompted a renewed interest in public property, forcing municipalities to position themselves in relation to the necessity to sell or keep it (or even to strategically acquire more of it). (2) Because efficiency became central, municipalities were compelled to develop more elaborated development strategies. (3) Together with the emergence of new planning challenges, land-use planning instruments are increasingly considered together with other instruments such as incentives and public real estate.

\section{Acknowledgements}

My thanks go to the different local authorities who kindly agreed to answer my questions. Thank you also to three anonymous reviewers for their constructive comments.

\section{Disclosure statement}

No potential conflict of interest was reported by the author.

\section{Funding}

This paper is an output of a project funded by the Swiss National Science Foundation [grant number PZ00P1_131862].

\section{Literature}

Adams, D., Disberry, A., Hutchison, N. \& Munjoma, T. (2002). Land Policy and Urban Renaissance: The Impact of Ownership Constraints in Four British Cities. Planning Theory \& Practice, 3(2), 195-217.

Brenner, N. (1998). Global Cities, Glocal States: Global City Formation and State Territorial Restructuring in Contemporary Europe. Review of International Political Economy, $5(1), 1-37$. 
Brenner, N. (2009). What is critical urban theory? City, 13(2-3), 198-207.

Cheever, F. (1996). Public Good and Private Magic in the Law of Land Trusts and Conservation Easements: A Happy Present and a Troubled Future. Denver University Law Review, 73(4), 1077-1102.

Davy, B. (2000). Mandatory Happiness? Land Readjustment and Property in Germany. In Y.-H. Hong, B. Needham (Eds.), Analyzing land readjustment. Economics, law, and collective action (pp. 37-55). Cambridge, MA: Lincoln Institute of Land Policy.

Dibben, P., \& Higgins, P. (2004). New Public Management: Marketisation, Managerialism and Consumerism. In P. Dibben, G. Wood, \& I. Roper (Eds). Contesting Public Sector Reforms. Critical Perspectives, International Debates. Houndmills: PalgraveMacmillan.

Eberlein, B. (1999). L’État régulateur en Europe. Revue française de science politique, 49(2), 205-230.

Fainstein, S.S. (2008). Mega-projects in New York, London and Amsterdam. International Journal of Urban and Regional Research, 32(4), 768-785.

Fulton, W. (1999). Guide to California Planning. Point Arena, CA: Solano Press Books.

Guillén, M. (2001). Is globalization civilizing, destructive or feeble? A critique of five key debates in the social science literature. Annual Review of Sociology, 27, 235-60.

Hartmann, T., \& Spit, T. (2015). Dilemmas of involvement in land management - Comparing an active (Dutch) and a passive (German) approach. Land Use Policy 42(1): 729-737.

Harvey, D. (2008). The Right to the City. New Left Review 53, 23-40.

Healey, P., \& Barrett, S.M. (1985). Land policy: towards a research agenda. In S.M. Barrett, P. Healey (Eds.) Land problems: Problems and alternatives (pp. 1-20). Aldershot: Gower.

Hengstermann, A., \& Gerber, J.-D. (2015). Aktive Bodenpolitik - Eine Auseinandersetzung vor dem Hintergrund der Revision des eidgenössischen Raumplanungsgesetzes. Flächenmanagement und Bodenordnung (FuB) 6, 241-250.

Hersperger A.M., Gennaio Franscini, M.-P., \& Kübler, D. (2014). Actors, Decisions and Policy Changes in Local Urbanization. European Planning Studies, 22(6), 1301-1319.

Hood, C. (1983). The tools of government. London: Macmillan.

Hughes, O.E. (2003). Public Management and Administration: An Introduction. New York: Palgrave Macmillan.

Jacobs, H.M., \& Paulsen, K. (2009). Property Rights: The Neglected Theme of 20th-Century American Planning. Journal of the American Planning Association, 75(2), 134-143.

Jessop, B. (2002). Liberalism, neoliberalism, and urban governance: A state-theoretical perspective. Antipode, 34(3), 452-472.

Kaufmann, V., \& Faith Strelec, J. (2011). Re-Thinking the City. Urban Dynamics and Motility. Lausanne: EPFL Press. 
Knoepfel, P., Csikos, M., Gerber, J.-D., \& Nahrath, S. (2012). Transformation der Rolle des Staates und der Grundeigentümer in städtischen Raumentwicklungsprozessen im Lichte der nachhaltigen Entwicklung. Politische Vierteljahresschrift, 3, 414-443.

Knoepfel, P., Finger, M., \& Haldemann, T. (1995). New Public Management. Swiss Political Science Review, 1(1), i-xv.

Krabben, E. van der, \& Jacobs, H. (2013). Public land development as a strategic tool for redevelopment: reflections on the Dutch experience. Land Use Policy, 30(1), 774-783.

Larner, W. (2003). Neoliberalism? Environment and Planning D: Society and Space, 21(5), $509-512$.

Lascoumes, P., \& Le Galès, P. (2005). Introduction: L'action publique saisie par ses instruments. In P. Lascoumes, \& P. Le Galès (Eds). Gouverner par les instruments (pp. 11-44). Paris: Presses de Science Po.

Leman, C.K. (2002). Direct Government. In L.M. Salamon (Ed.). The tools of government a guide to the new governance (pp. 48-79). Oxford: Oxford University Press.

Linder, W. (1994). Swiss Democracy: Possible Solutions to Conflict in Multicultural Societies. New York: St. Martin's Press.

Mäntysalo, R., Saglie, I.-L., \& Cars, G. (2011). Between Input Legitimacy and Output Efficiency: Defensive Routines and Agonistic Reflectivity in Nordic Land-Use Planning. European Planning Studies, 19(12), 2109-2126.

Matthey, L. (2015). Malaise dans la profession. Les urbanistes suisses face aux transformations de leur métier. Metropolitiques, 14 january 2015. URL: http://www.metropolitiques.eu/Malaise-dans-la-profession.html

Morris, A.W. (2008). Easing conservation? Conservation easements, public accountability and neoliberalism. Geoforum, 39(3), 1215-1227.

Muggli, R. (n.d.). Spatial planning in Switzerland: a short introduction. Bern: VLP-ASPAN. URL: http://www.vlp-aspan.ch/sites/default/files/at_en.pdf

Nahrath, S. (2005). Le rôle de la propriété foncière dans la genèse et la mise en œuvre de la politique d'aménagement du territoire. In A. Da Cunha, P. Knoepfel, J.-P. Leresche, \& S. Nahrath (Eds). Enjeux du développement urbain durable transformations urbaines, gestion des ressources et gouvernance (pp. 299-328). Lausanne: PPUR.

Needham, B., \& Verhage, R. (1998). The effects of land policy: Quantity as well as quality is important. Urban Studies, 35(1), 25-44.

Osborne, D., \& Gaebler, T. (1992). Reinventing government: how the entrepreneurial spirit is transforming the public sector. New York, N.Y.: Plume.

Pierre, J. (1999). Models of Urban Governance. The Institutional Dimension of Urban Politics. Urban Affairs Review, 34(3), 372-396. 
Pollitt, C., \& Bouckaert, G. (2011). Public Management Reform: A Comparative Analysis New Public Management, Governance, and the Neo-Weberian State. Oxford: Oxford University Press.

Ritz, A. (2005). 10 Jahre Verwaltungsreform in den Schweizer Kantonen. Eine Bilanz aus der Sicht von Legislative und Exekutive. In: A. Lienhard, A. Ritz, R. Steiner, \& A. Ladner (Eds). 10 Jahre New Public Management in der Schweiz: Bilanz, Irrtümer und Erfolgsfaktoren. Bern: Haupt.

Ruegg, J. (2008). Aménagement du territoire et question foncière: quelques points de repère. Urbia 6, 9-26.

Sager, T., \& Sørensen, C.H. (2011). Planning analysis and political steering with new public management. European Planning Studies, 19(2), 217-241.

Salamon, L.M. (Ed.). (2002). The tools of government a guide to the new governance. Oxford: Oxford University Press.

Schedler, K. (2003). Local and regional public management reforms in Switzerland. Public Administration, 81(2), 325-344.

Scholl, B., \& Elgendy, H. (2011). Siedlungsflächenreserven in der Schweiz. Anforderungen an eine schweizweite Übersicht. Geomatik Schweiz, 8, 380-383.

Schuler, M., \& Ruzicka-Rossier, M. (2011). Une décennie de politique d'agglomération. Tracés, 05/06, 4-15.

Schuler, M., Dessemontet, P., \& Joye, D. (2005). Les niveaux géographiques de la Suisse. Bern: OFS.

Sieber, H. (1970). Bodenpolitik und Bodenrecht. Bern: Haupt.

Söderström, O., Klauser, F., Piguet, E., \& Crot, L. (2012). Dynamics of Globalisation: Mobility, Space and Regulation. Geographica Helvetica, 67(1/2), 43-54.

Steiner, R., \& Ladner, A. (2006). Die Schweizer Gemeinden im Fokus - Ergebnisse der Gemeindebefragung 2005. In A. Glatthard, \& U. Isch (Eds). Perspektiven für Gemeindefinanzen (pp. 8-34). Bern: ESG.

Stoker, G. (1995). Regime Theory and Urban Politics. In: D. Judge, G. Stoker, \& H. Wolman (Eds), Theories of urban politics (pp. 54-71). London: Sage.

Süess, A., \& Gmünder, M. (2005). Weniger Zersiedlung durch handelbare Flächennutzungszertifikate? DISP 160, 58-66.

Swank, D. \& Steinmo, S. (2002). The new political economy of taxation in advanced capitalist democracies. American Journal of Political Science, 46, 477-489.

Swyngedouw, E., Moulaert, F., et al. (2002). Neoliberal urbanization in Europe: Large-scale urban development projects and the New Urban Policy. Antipode, 34(3), 542-577. 
Theurillat, T., \& Crevoisier, O. (2013). The sustainability of a financialized urban megaproject: the case of Sihlcity in Zurich. International Journal of Urban and Regional Research, 37(6), 2052-2073.

Theurillat, T., \& Crevoisier, O. (2014). Sustainability and the anchoring of capital: negotiations surrounding two major urban projects in Switzerland. Regional Studies, 48(3), 501-515.

Tillemans, L., Weber, P., Ruegg, J., \& Prélaz-Droux, R. (2012). Maîtriser le foncier pour maîtriser la production urbaine. Working paper COST TU602 Land management for urban dynamics. UNIL / IHEIG.

Bühlmann, L., Haag, H., Jud,, B., Kissling, S., \& Spori, N. (2011). Einführung in die Raumplanung. Bern: VLP-ASPAN.

VLP-ASPAN (2013). Rechtliche Möglichkeiten zur Baulandmobilisierung in den Kantonen und Gemeinden. Raum \& Umwelt, September 5/2013.

Weber, M. (1968). Economy and society. An outline of interpretive sociology. New York: Bedminster Press.

Weber, P., Prélaz-Droux, R., Ruegg J., \& Tillemans, L. (2011). How to supply enough land at the right place and time? An answer given by the canton of Vaud, Switzerland. In: M. Tira, E. Van der Krabben \& B. Zanon (Eds), Land management for urban dynamics: innovative methods and practices in a changing Europe, Santarcangelo di Romagna: Maggioli.

Weiss, L. (1998). The myth of the powerless state. New York: Cornell University Press.

Whitehead, M. (2003). (Re)Analysing the sustainable city: nature, urbanisation and the regulation of socio-environmental relations in the UK. Urban Studies, 40(7), 11831206.

Wright, J.B., \& Czerniak, R.J. (2000). The rising importance of voluntary methods of land use control in planning. Journal of Planning Education and Research, 19(4), 419-423.

Zimmerli, U. (1990). Zum Stand der Bodenpolitik und des Bodenrechts. In: B. Knapp (Ed.) Perspektiven des Raumplanungs- und des Bodenrechts (pp. 161-189). Basel, Helbing \& Lichtenhahn. 
Table 1. List of selected municipalities. Source: Swiss Federal Office of Statistics

\begin{tabular}{|c|c|c|c|c|}
\hline Municipality & Canton & $\begin{array}{c}\text { French/German- } \\
\text { speaking }\end{array}$ & Total population & Surface (ha) \\
\hline Aarau & Aargau & G & 15753 & 1233 \\
\hline Muttenz & Basel-Land & $\mathrm{G}$ & 17119 & 1664 \\
\hline Biel/Bienne & Bern & $\mathrm{F} / \mathrm{G}$ & 50013 & 2123 \\
\hline Köniz & Bern & G & 37974 & 5101 \\
\hline Bulle & Fribourg & $\mathrm{F}$ & 17494 & 2387 \\
\hline Carouge & Geneva & $\mathrm{F}$ & 19721 & 270 \\
\hline Meyrin & Geneva & $\mathrm{F}$ & 20329 & 994 \\
\hline Kriens & Lucerne & G & 25893 & 2734 \\
\hline La Chaux-de-Fonds & Neuchâtel & $\mathrm{F}$ & 37240 & 5566 \\
\hline Neuchâtel & Neuchâtel & $\mathrm{F}$ & 32592 & 1810 \\
\hline Freienbach & Schwyz & G & 15681 & 1378 \\
\hline Solothurn & Solothurn & G & 15623 & 628 \\
\hline Wil & St. Gallen & G & 17678 & 762 \\
\hline Frauenfeld & Thurgau & G & 22665 & 2737 \\
\hline Monthey & Valais & $\mathrm{F}$ & 16302 & 2863 \\
\hline Renens & Vaud & $\mathrm{F}$ & 18982 & 296 \\
\hline Morges & Vaud & $\mathrm{F}$ & 14615 & 385 \\
\hline Illnau-Effretikon & Zurich & G & 15338 & 2529 \\
\hline Thalwil & Zurich & $\mathrm{G}$ & 16631 & 550 \\
\hline
\end{tabular}


Table 2. Data summarizing interviews performed in the nineteen local authorities. For each indicator, interviewees were asked to decide on a scale of 5 (reduced to 3 in the table) whether the situation had changed in comparison with the 1990s. For each question, the answer supported by a majority of interviewees is highlighted in bold. The total number of answers is the sum of all interviews performed in all nineteen municipalities. Chi-square tests indicate no significant differences of opinions between the three categories of actors interviewed (politicians, planners and public real-estate managers). Their answers are therefore presented in an aggregated form. A number smaller than the total number of interviews (53) indicates that some interviewees did not respond to the question.

\begin{tabular}{|c|c|c|c|c|}
\hline & $\begin{array}{l}\text { Total \# of } \\
\text { answers }\end{array}$ & $\begin{array}{l}\text { Growing } \\
\text { trend (\%) }\end{array}$ & $\begin{array}{l}\text { Stable } \\
\text { trend (\%) }\end{array}$ & $\begin{array}{l}\text { Decreasing } \\
\text { trend }(\%)\end{array}$ \\
\hline \multicolumn{5}{|l|}{$\begin{array}{l}\text { NPM reforms in connection with land-use } \\
\text { planning practices }\end{array}$} \\
\hline \multicolumn{5}{|l|}{$\begin{array}{l}\text { 1. Increased competition (today in comparison with } \\
\text { 1990)? }\end{array}$} \\
\hline - Competition among administrative services & 50 & $10(20 \%)$ & $15(30 \%)$ & $25(50 \%)$ \\
\hline - Competition among local authorities & 50 & $30(60 \%)$ & $11(22 \%)$ & $9(18 \%)$ \\
\hline \multicolumn{5}{|l|}{$\begin{array}{l}\text { 2. Increased link between financial considerations } \\
\text { and real-estate management? }\end{array}$} \\
\hline $\begin{array}{l}\text { - Accounting rules for public real estate aiming to } \\
\text { increase transparency and cost consciousness }\end{array}$ & 32 & $25(78.1 \%)$ & $7(21.9 \%)$ & 0 \\
\hline - Profitability objectives for public real estate & 44 & $22(50 \%)$ & $20(45.5 \%)$ & $2(4.5 \%)$ \\
\hline - Pressure to sell public real estate & 50 & $13(26 \%)$ & $19(38 \%)$ & $18(36 \%)$ \\
\hline \multicolumn{5}{|l|}{$\begin{array}{l}\text { 3. Increased number of public-private } \\
\text { partnerships? }\end{array}$} \\
\hline $\begin{array}{l}\text { - Implementation of projects together with private } \\
\text { partners (incl. public-private partnership) }\end{array}$ & 52 & $34(65.4 \%)$ & $16(30.8 \%)$ & $2(3.8 \%)$ \\
\hline - Outsourcing of public tasks to the private sector & 49 & $13(26.5 \%)$ & $31(63.3 \%)$ & $5(10.2 \%)$ \\
\hline
\end{tabular}

\section{Evolution of practices in land-use planning}

\begin{tabular}{lcccc}
$\begin{array}{l}\text { 1. Increased use of statutory interventions? } \\
\text { - Structure plans ("Richtplan”, "plan directeur”) }\end{array}$ & 41 & $\mathbf{2 9}(70.7 \%)$ & $11(26.8 \%)$ & $1(2.4 \%)$ \\
(binding) & & & & \\
- Local zoning plans & 39 & $12(30.8 \%)$ & $\mathbf{2 7}(69.2 \%)$ & 0 \\
- Masterplan, guidelines (non-binding) & 36 & $\mathbf{2 6}(72.2 \%)$ & $9(25 \%)$ & $1(2.8 \%)$ \\
- Private district plans & 36 & $\mathbf{2 4}(66.7 \%)$ & $10(27.8 \%)$ & $2(5.6 \%)$ \\
\hline $\begin{array}{l}\text { 2. Trend toward improvement of general } \\
\text { framework conditions? }\end{array}$ & & & & \\
- Inciting instruments (taxes, subsides, incentives) & 44 & $\mathbf{2 4}(54.5 \%)$ & $19(43.2 \%)$ & $1(2.3 \%)$ \\
- Role as a facilitator & 45 & $\mathbf{2 8}(62.2 \%)$ & $17(37.8 \%)$ & 0 \\
\hline 3. Increased intervention through private law? & & & & \\
- Public-private partnership, contract, convention & 46 & $\mathbf{3 2}(69.6 \%)$ & $14(30.4 \%)$ & 0 \\
- Non-monetary compensation & 35 & $\mathbf{2 0}(57.1 \%)$ & $15(42.9 \%)$ & 0 \\
- Long-term building leases & 45 & $13(28.9 \%)$ & $\mathbf{2 1}(46.7 \%)$ & $11(24.4 \%)$ \\
- Public real estate used to steer development & 45 & $\mathbf{2 6}(57.8 \%)$ & $18(40 \%)$ & $1(2.2 \%)$ \\
\hline
\end{tabular}



Table 3. Typology of the strategies implemented by local authorities in response to NPM reforms. Ideal types are interpretations of the empirical data; they are mental constructs resulting from a deliberate simplification and exaggeration of crucial aspects of the empirical reality. As heuristic devices to be used to discuss the empirical reality, the three ideal types presented below show that NPM can lead to different outcomes at the local level depending on the priorities of the political-administrative actors. NPM can lead to a reinforcement of actors in charge of planning ("reinforcement strategy"). However, it can also lead to minimal public intervention ("Laissez-faire strategy") or to a reinforcement of land deals and other private-law interventions whose context tends to escape public scrutiny ("end-justifies-the-means strategy").

\begin{tabular}{|c|c|c|c|}
\hline & Laissez-faire strategy & Reinforcement strategy & $\begin{array}{l}\text { End-justifies-the-means } \\
\text { strategy }\end{array}$ \\
\hline $\begin{array}{l}\text { Characteristics of NPM } \\
\text { reforms }\end{array}$ & $\begin{array}{l}\text { NPM leads to small state } \\
\text { and correspondingly } \\
\text { minimal intervention in } \\
\text { planning issues }\end{array}$ & $\begin{array}{l}\text { NPM leads to a } \\
\text { reinforcement of the } \\
\text { planning action through } \\
\text { the increased array of } \\
\text { tools available }\end{array}$ & $\begin{array}{l}\text { NPM leads to a } \\
\text { reinforcement of the } \\
\text { executive through the } \\
\text { import of private sector } \\
\text { practices. Local authority } \\
\text { behaves as would any } \\
\text { other private company }\end{array}$ \\
\hline Public law instruments & Minimal & $\begin{array}{l}\text { Standard tools }+ \text { all the } \\
\text { other participatory plans }\end{array}$ & $\begin{array}{l}\text { Standard tools }+ \text { private } \\
\text { plans }\end{array}$ \\
\hline Private law instruments & Sale of public assets; PPP & $\begin{array}{l}\text { Private law used to } \\
\text { reinforce public law } \\
\text { through targeted action } \\
\text { (e.g., acquisition of } \\
\text { strategic parcels) }\end{array}$ & $\begin{array}{l}\text { Private law used to } \\
\text { circumvent public law } \\
\text { and increase efficiency } \\
\text { (reinforcement of the } \\
\text { executive at the expense } \\
\text { of the legislative) }\end{array}$ \\
\hline $\begin{array}{l}\text { Expected effects on } \\
\text { spatial development }\end{array}$ & $\begin{array}{l}\text { No willingness to thwart } \\
\text { unsustainable } \\
\text { development trends } \\
\text { through specific public } \\
\text { intervention }\end{array}$ & $\begin{array}{l}\text { Social and environmental } \\
\text { sustainability goals }\end{array}$ & $\begin{array}{l}\text { Economic sustainability } \\
\text { goals }\end{array}$ \\
\hline Development priorities & $\begin{array}{l}\text { Management of self- } \\
\text { sustained growth }\end{array}$ & $\begin{array}{l}\text { Redevelopment of } \\
\text { (partially) built areas }\end{array}$ & $\begin{array}{l}\text { Need to boost declining } \\
\text { local economy }\end{array}$ \\
\hline Political legitimacy & Free-market oriented & $\begin{array}{l}\text { Political support through } \\
\text { democratic legitimacy } \\
\text { (primary legitimacy) }\end{array}$ & $\begin{array}{l}\text { Consensus through } \\
\text { appreciation of outputs } \\
\text { (secondary legitimacy) }\end{array}$ \\
\hline Bureaucratic traditions & $\begin{array}{l}\text { No consensus concerning } \\
\text { the acquisition of public } \\
\text { land }\end{array}$ & $\begin{array}{l}\text { Well-established process } \\
\text { of acquiring public } \\
\text { parcels to increase stock }\end{array}$ & $\begin{array}{l}\text { Consensus concerning } \\
\text { public intervention } \\
\text { through acquisition; stock } \\
\text { of public parcels available }\end{array}$ \\
\hline
\end{tabular}

